\title{
Studies in chronic lymphocytic leukaemia II. Lymphocyte markers, cellular and humoral immunity and the effect of treatment
}

\author{
M. B. BAZERBASHI* \\ M.B., Ch.B., D.C.P., Ph.D.
}

I. Chanarin

M.D., F.R.C.Path.

\author{
A. M. Denman \\ M.B., F.R.C.P. \\ Haematology and Immunology Divisions, Clinical Research Centre, \\ Northwick Park Hospital, Watford Road, Harrow, Middlesex
}

\begin{abstract}
Summary
Observations were made on 15 patients with chronic lymphocytic leukaemia, 3 with non-Hodgkin's lymphoma, and 18 healthy controls. These include characterization of lymphocytes, assessment of humoral and cell-mediated immunity and the effect of treatment. Those responding to therapy showed a disappearance of 'null' lymphocytes from the blood with improvement in clinical and haematological parameters. Their immune capacity, however, remained unchanged or continued to deteriorate.
\end{abstract}

\section{Introduction}

Patients with chronic lymphocytic leukaemia (CLL) have an abnormally high proportion of $B-$ lymphocytes in the peripheral blood. This was shown in CLL by demonstrating immunoglobulin on the lymphocyte surface (Pernis et al., 1971; Wilson and Nossal, 1971; Unanue et al., 1971; Papamichail, Brown and Holborow, 1971; Rabillino and Grey, 1972; Van Boxel et al., 1972a; Preud'Homme and Seligmann, 1972; Ross et al., 1973; Seligmann, Preud'Homme and Brouhet, 1973; Haegert, Hallberg and Coombs, 1974; Seligmann, 1974; Fu and Kunkel, 1974; Kubo, Grey and Pirosky, 1974; Seligmann, 1975), by demonstrating complement receptors on the cell surface (Pincus, Bianco and Nussenzweig, 1972; Shevach, Herberman and Frank, 1972; Jondal, Holm and Wigzell, 1972; Ross et al., 1973; Huber, Michlmayr and Huber, 1974; Cohnen et al., 1974): or by demonstrating lymphocyte binding of aggregated IgG (Dickler et al., 1973; Augner, Cohnen and Brittinger, 1974; Huber et al., 1974).

T-lymphocytes in CLL are diluted by virtue of the

* This work formed part of the Ph.D. thesis submitted to the University of London. increase in B-cells (Melief, Schweitzer and Eijsvooge 1973; Wybran, Chantler and Fudenberg, 1973? Fernandez, MacSween and Langley, 1975) but the absolute members are maintained in most cases.

In addition, there are lymphocytes which are neither $T$-cells nor show the usual reactions of B-cells. These have been termed null-cells. They gre also increased in CLL (Nath et al., 1975).

Hypogammaglobulinaemia is present in between 35 and $75 \%$ of patients with chronic lymphocy leukaemia (Jim, 1957; Boggs and Fahey, 1960 Fairley and Scott, 1961; Miller, 1962; Schumanno 1963; Mobarak and Brody, 1967; Buckley an Dorey, 1971; Scamps, Streeter and O'Neill, $1971 \AA^{\circ}$ Hansen, 1973; Slungaard and Smith, 1974). Man $\overrightarrow{8}$ of these patients show an increased liability te infection with both bacteria and viruses (Hansen 1973). Between 5 and $13 \%$ of patients get herpes. zoster (Videbaek, 1949; Hansen, 1973). Bacteriał infections most frequently involve the respirator tract.

The present authors report observations on the lymphocytes in patients with CLL and lymphom including comparison of cells in the blood and lympR gland, on the results of tests for immunity and the effect of therapy on these observations.

\section{Patients studied}

Observations were made on 15 patients with CLE, 3 with lymphoma and 18 normal subjects. The patients with CLL (cases 1-15) varied from those who were well clinically with only an elevated tot $\mathbb{\Psi}$ lymphocyte count, to those with anaemia, marrow infiltration, glandular enlargement and splenoథ megaly (Table 1). One patient had an autoimmune haemolytic anaemia (case 14). The initial blood count is shown in Table 2. 
TABLE 1. Clinical findings in the patients

\begin{tabular}{|c|c|c|c|c|c|c|c|}
\hline Patient & Age & Sex & $\begin{array}{l}\text { State of } \\
\text { health }\end{array}$ & $\begin{array}{c}\text { Lymph- } \\
\text { adenopathy }\end{array}$ & $\begin{array}{l}\text { Splenomegaly } \\
\text { (in cm below } \\
\text { costal margin) }\end{array}$ & $\begin{array}{l}\text { Hepatomegaly } \\
\text { (in cm below } \\
\text { costal margin) }\end{array}$ & $\begin{array}{c}\text { Marrow } \\
\text { infiltration } \\
(\% \text { lymphocytes })\end{array}$ \\
\hline 1 & 44 & $\mathbf{M}$ & Good & - & - & - & 48 \\
\hline 2 & 65 & $\mathbf{F}$ & Good & - & - & - & 34 \\
\hline 3 & 59 & $\mathbf{M}$ & Good & - & - & - & 47 \\
\hline 4 & 64 & $\mathbf{M}$ & Good & +1 & - & - & 35 \\
\hline 5 & 75 & $\mathbf{M}$ & Good & - & - & - & 52 \\
\hline 6 & 55 & $\mathbf{F}$ & Good & - & - & - & 49 \\
\hline 7 & 41 & $\mathbf{M}$ & Good & +3 & 7 & 1 & 80 \\
\hline 8 & 60 & $\mathbf{M}$ & Good & +2 & - & - & 74 \\
\hline 9 & 73 & $\mathbf{F}$ & Moderate & +3 & 8 & - & 98 \\
\hline 10 & 48 & $\mathbf{F}$ & Poor & +3 & 3 & 4 & 92 \\
\hline 11 & 74 & $\mathbf{M}$ & Good & +3 & 10 & 2 & 97 \\
\hline 12 & 67 & $\mathbf{F}$ & Poor & - & 10 & - & 72 \\
\hline 13 & 65 & F & Poor & +1 & 4 & - & 78 \\
\hline 14 & 73 & $\mathbf{M}$ & Poor & +3 & 8 & 5 & 65 \\
\hline 15 & 79 & $\mathbf{M}$ & Poor & - & 15 & 4 & 78 \\
\hline 16 & 63 & $\mathbf{M}$ & Poor & - & 20 & 3 & 78 \\
\hline 17 & 70 & $\mathbf{M}$ & Good & +3 & - & - & \\
\hline 18 & 68 & $\mathbf{M}$ & Poor & +3 & 12 & 1 & 43 \\
\hline
\end{tabular}

- No enlargement, + one enlargement in one zone, +2 enlargement of several groups of glands, +3 generalized lymphadenopathy. Cases 1-15 had CLL; cases 16-18 had lymphoma.

Cases 16, 17 and 18 had a lymphoma of lymphocytic type; in 2 of these, abnormal lymphoid cells were present in the blood. Both these patients died within 4 and 10 weeks of diagnosis. The third patient with lymphosarcoma showed a good response to cytotoxic therapy (mustine, vincristine, prednisone and procarbazine).

Cases 13 and 15 had repeated chest infections and required gammaglobulin supplements; cases 9, 10 and 12 had herpes zoster infection complicated by encaphalitis in case 12 and hepatitis in case 10 . Chronic emphysema and bronchitis occurred in cases 14 and 15 . Gram-negative septicaemia occurred as a complication in case 10 and case 16 with lymphoma.

Five patients died (cases 10, 14, 15, 16 and 18). Follow-up ranged from 1 to 2.5 years. Treatment was with chlorambucil with or without prednisone. Cases with heavy marrow infiltration were treated successfully with a mustine, procarbazine, vincristine, prednisone (MOPP) regime. Five patients remained untreated (cases 1, 2, 3, 4, 6) and one (case 5) required treatment 2 years after diagnosis. Tests were carried out before treatment was given except in case 15 who had had intermittent therapy elsewhere over a period of 10 years. He was not on treatment when tested.

\section{Methods}

The methods used were described in detail by Bazerbashi (1975).

Collection of lymphocytes. Between $10-50 \mathrm{ml}$ of blood were taken into heparin or defibrinated.
Two volumes of blood were added to one volume of plasmagel and left at room temperature for 20 min. The supernatant containing lymphocytes was transferred to an equal volume of Ficoll-Triosil mixture and centrifuged at about $600 \mathrm{~g}$ for $25 \mathrm{~min}$. Lymphocytes and monocytes were harvested from the interface into $25 \mathrm{ml}$ RPM1 solution and washed twice. In CLL, less than $1 \%$ of the cells were monocytes. With normal blood a trace of metallic iron powder was added and after $30 \mathrm{~min}$ the monocytes attracted to the bottom of the universal container with a magnet. The supernatant was harvested.

Thinly sliced lymph glands were emulsified against the mesh of a stainless steel wire tea strainer. The suspension was filtered through surgical gauze and washed in RPM1 solution. All suspensions were tested for viability by the trypan blue viability test.

Ficoll-Triosil mixture. Ten parts of Triosil $(20 \mathrm{ml}$ Triosil 440 and $24.2 \mathrm{ml}$ water) were mixed with 24 parts of sterile $9 \%$ Ficoll solution.

$R P M 1 p H 7 \cdot 2$. The solution was purchased from Gibco-Biocult Ltd.

Demonstration of surface immunoglobulins. Lymphocytes were suspended in a concentration of 2 to 3 million cells $/ \mu \mathrm{l}$, one $\mathrm{ml}$ added to each of 7 plastic $1.7 \times 5$-cm tubes, centrifuged and supernatant discarded. About $50 \mu l$ of polyvalent fluorescein-conjugated rabbit antiserum against heavy and light chains (Mercia diagnostic laboratories) were added to one tube and unconjugated rabbit antisera against $\gamma, \alpha$ and $\mu$ heavy chains and against $\kappa$ and $\lambda$ light chains added to the remaining tubes. The last tube, serving as a control had $50 \mu l$ of swine antirabbit fluorescein-labelled serum added. 


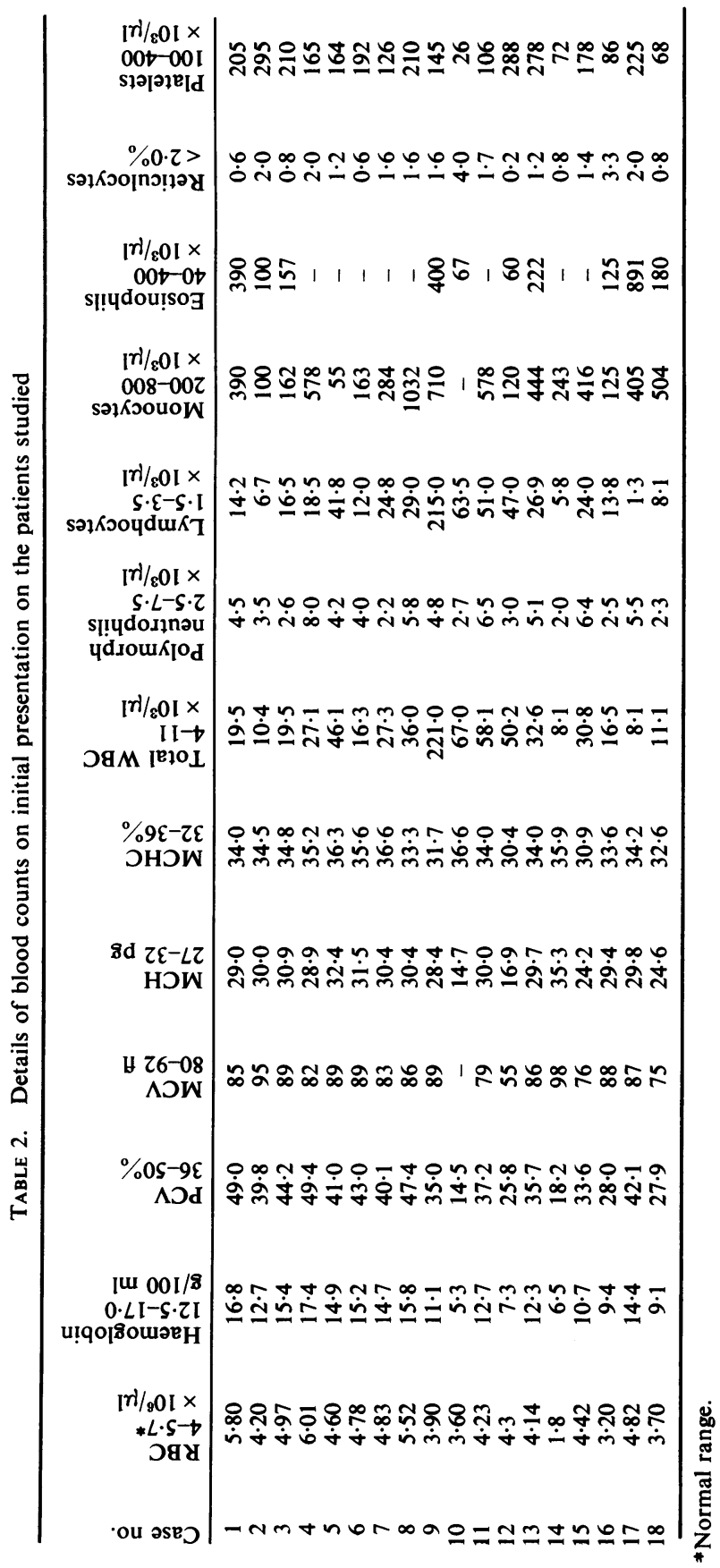


After incubation for $60 \mathrm{~min}$ at $4^{\circ} \mathrm{C}$, the cells were washed 3 times and anti-rabbit fluoresceinconjugated serum was added to the tubes containing monospecific antisera. These were again left for $60 \mathrm{~min}$ at $4^{\circ} \mathrm{C}$ and washed 3 times in phosphatebuffered saline. Finally the cells were resuspended in buffered glycerin (glycerin 1 part, phosphatebuffered saline 2 parts) and examined by ultraviolet microscopy. The total number of cells and those exhibiting fluorescence were noted.

When the great majority of cells showed fluorescence the cells were re-incubated with $0.25 \%$ trypsin in RPM1 at $\mathrm{pH} 7 \cdot 2$ to remove adsorbed serum, immunoglobulin or immune complexes, and reexamined.

Demonstration of surface complement receptors. Sheep red blood cells (SRBC) were washed in phosphate-buffered saline and suspended to give a $5 \%$ suspension. One in 1000 (sub-haemolytic dose) of SRBC antiserum was added, left at $37^{\circ} \mathrm{C}$ for $30 \mathrm{~min}$, washed and $1 / 5$ dilution of mouse complement (pooled serum from 10 mice bled by heart puncture) added. The suspension was incubated for a further $30 \mathrm{~min}$ at $30^{\circ} \mathrm{C}$, washed in phosphatebuffered saline and resuspended in RPMI with $10 \%$ heat inactivated and sheep cell-absorbed fetal calf serum to give a $5 \%$ suspension.

Two million lymphocytes in $0.5 \mathrm{ml}$ were mixed with $0.5 \mathrm{ml}$ sensitized sheep cells and rotated for 20 min at $37^{\circ} \mathrm{C}$. A drop was transferred to a white cell counting chamber and examined. Lymphocytes surrounded by not $<4$ sheep cells were regarded as forming rosettes. The control preparation consisted of sheep cells without complement.

Spontaneous sheep-cell rosettes. Lymphocytes were suspended to give a concentration of $5 \times 10^{6} / \mathrm{ml}$. Sheep cells were suspended to give a $2 \%$ suspension; $0.1 \mathrm{ml}$ lymphocytes, $0.1 \mathrm{ml}$ inactivated and sheep cell-absorbed fetal calf serum and $0.2 \mathrm{ml}$ sheep red cell suspension were incubated at $37^{\circ} \mathrm{C}$ for $10 \mathrm{~min}$, centrifuged at $200 \mathrm{~g}$ for $5 \mathrm{~min}$ and left at room temperature for one hr. They were resuspended by agitation and examined for rosettes in a counting chamber.

Null-lymphocytes. When the proportion of cells showing spontaneous sheep cell rosettes (T-cells) and those showing the characteristics of B-cells were added together, the sum accounted for $57-91 \%$ in normal subjects. The remaining cells were termed null-cells.

Measurement of lymphocyte size. About $5 \times 10^{6}$ lymphocytes were resuspended in $5 \mathrm{ml}$ RPM1 and $10 \mathrm{ml}$ Isoton (Coulter Electronics) and size measured in a Coulter Counter Model B using a $100 \mu$ diameter orifice tube. The results were recorded on an automatic particle size distribution analyser, model $\mathbf{J}$. The machine was calibrated with human red cells whose MCV had been measured on a Coulter Counter model S.

\section{Tests for humoral response}

Escherichia coli antibodies. Antibodies in sera were looked for by an agglutination test with human red cells on to which $E$. coli antigens were absorbed (Webster, Efter and Asherson, 1974).

Pneumococcal polysaccharide type II antibodies. $1 \mathrm{mg}$ of the antigen in $0.1 \mathrm{ml}$ was given intradermally and response followed by titrating a pre- and postinjection (day 12) serum sample using a haemagglutination technique with antigen absorbed on to sheep cells (Barker, Stashak and Prescott, 1969; Gold and Fudenberg, 1967).

Haemophilus influenzae, E. coli, Staphyloccus aureus antibodies. Antibodies were looked for by injecting $0.1 \mathrm{ml}$ of each antigen intradermally in the forearm. A control consisted of suspending fluid only. Results were read at $5 \mathrm{~min}, 4,8$ and $16 \mathrm{hr}$. Zone of induration, and erythema were measured.

Immunoglobulin levels. IgG, IgA and IgM levels were measured (Mancini, Carbonara and Herman, 1965).

\section{Tests for cell-mediated response}

Candida albicans and mumps. Antigens were injected intradermally $(0.1 \mathrm{ml})$. A control was set up. The reaction was read at $48 \mathrm{hr}$. Purified protein derivative (PPD) (undiluted) was given by a multiple puncture method and read at $48 \mathrm{hr}$. 2,4 Dinitrochlorobenzene (DNCB) $0.1 \mathrm{ml}$ as a sensitizing solution $(0.5 \mathrm{~g}$ in $10 \mathrm{ml}$ acetone) was applied to the inner aspect of the upper arm, covered with gauze and left for 7 days. After 7 days $0.1 \mathrm{ml}$ of test solution (the above diluted 1 in a 1000) was applied to the other arm and read after $48 \mathrm{hr}$ as either negative, discrete vesicle with induration, confluent vesicle, or induration, bullae, or ulceration.

Antigens. PPD was obtained from Evans Ltd; DNCB from Merck; mumps antigen from Eli Lilly; E. coli, Staph. aureus and C. albicans from Bencard; pneumococcal polysaccharide from Wellcome.

\section{Results}

$B$-, $T$ - and null-cells (Table 3)

The percentage of B-cells in controls ranged from 5 to $23 \%$ (mean $12 \cdot 1$ ) and in CLL this ranged from 18 to $66 \%$ (mean 36.4). Expressed as absolute numbers 14 out of 15 patients had more than 2300 $\mathrm{B}$-cells/ $\mu \mathrm{l}$ which was the upper limit in controls. The range of B-cells was from 1620 to $68000 / \mu l$. Unfortunately a total WBC count was not done on the control group and normal absolute numbers were based on a normal WBC range of 4000 to 1000 cells $/ \mu l$. 


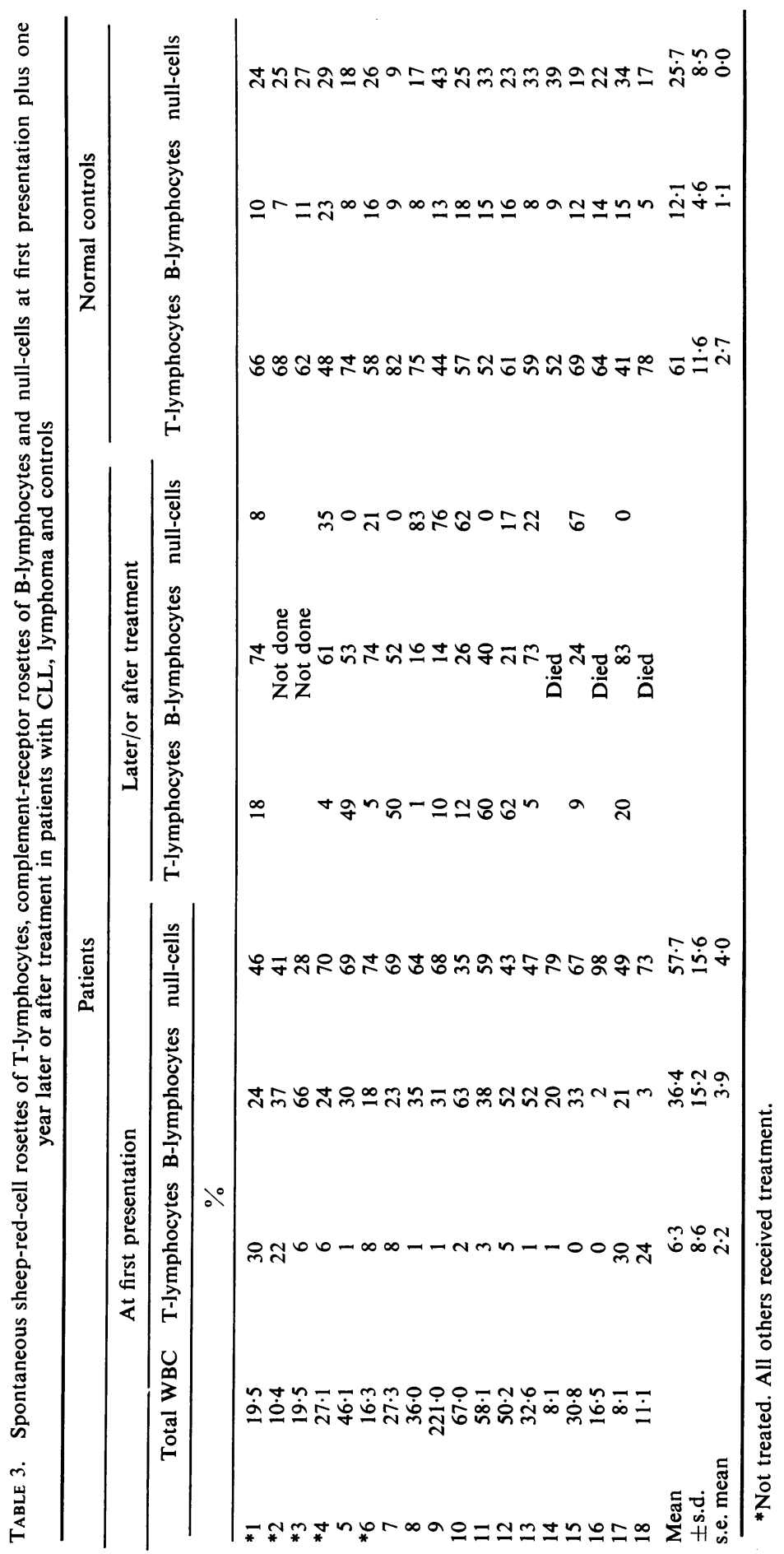


Null-cells were between 9 and $43 \%$ in controls $(360-4300 / \mu l)$ and were increased in numbers in all patients with CLL $(4300-34000 / \mu l)$. The 3 patients with lymphoma had a normal number of B-cells, but 2 had an increased number of null-cells $(8100$ and $16000 / \mu l)$.

Eight of 15 patients with CLL had normal T-cell numbers and 7 had reduced numbers. These were low in one patient with lymphoma. Figure 1 shows this expressed as a $\%$ of total cells.

\section{Nature of surface immunoglobulin}

In 13 control subjects, cells reacting with anti-IgG, IgA and IgM constituted $7.9,1.5$ and $9.5 \%$ of the total respectively. The ratio of $\kappa$ to $\lambda$ light chains was $12: 7(1 \cdot 7)$.

There was a significant rise in the proportion of cells carrying an IgM immunoglobulin in CLL (Table 4), IgG predominated in 3 patients and IgM in 4 patients. In addition, there was a marked disturbance in the light chain distribution. Three showed a preponderance of $\kappa$ chains and 4 a preponderance of $\lambda$ chains. The $\kappa / \lambda$ ratio was abnormal in all but 2 patients with CLL, confirming the probably monoclonal origin of this disease (Fig. 2).

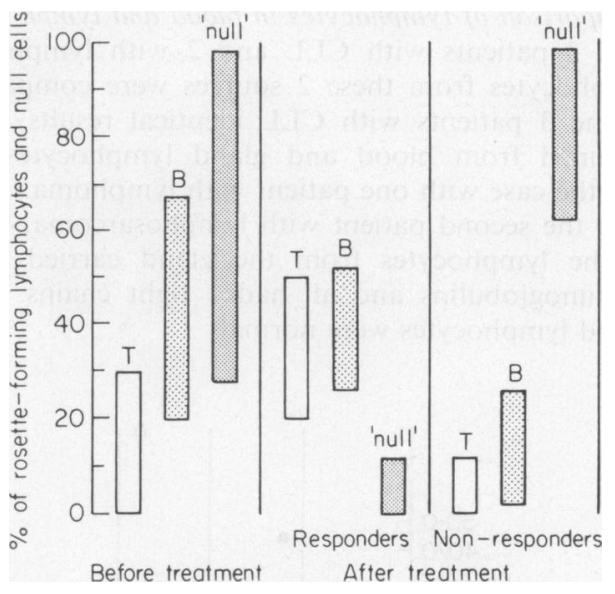

Fig. 1. Mean percentage of T, B, and null-cells before and after treatment. $\mathrm{T}=\mathrm{T}$-lymphocytes, $\mathrm{B}=\mathrm{B}$-lymphocytes.

Case 16 with lymphoma had lymphocytes with $98 \%$ of cells carrying IgM, and $97 \%$ of these cells had $\lambda$ light chains.

TABLE 4. B-cell identification by surface staining in the patients before treatment Per cent. of stained cells using the following antisera

\begin{tabular}{|c|c|c|c|c|c|c|c|}
\hline Patient & Polyvalent & IgG & $\operatorname{Ig} A$ & IgM & $\kappa$ & $\lambda$ & $\kappa / \lambda$ ratio \\
\hline 1 & 27 & 17 & 3 & 10 & 10 & 24 & 0.4 \\
\hline 2 & 32 & 25 & 4 & 10 & 32 & 10 & $3 \cdot 2$ \\
\hline 3 & 47 & 8 & 0 & 33 & 18 & 34 & 0.5 \\
\hline 4 & 74 & 67 & 5 & 23 & 14 & 72 & $0 \cdot 2$ \\
\hline 5 & 88 & 12 & 6 & 56 & 80 & 18 & $4 \cdot 4$ \\
\hline 6 & 37 & 3 & 0 & 36 & 10 & 25 & 0.4 \\
\hline 7 & $46(52) \dagger$ & $10(13)$ & $4(6) \dagger$ & $33(34) \dagger$ & $44(40) \dagger$ & $13(13) \dagger$ & $3 \cdot 4$ \\
\hline$* 8$ & 46 & 2 & 5 & 35 & 45 & 0 & 0.0 \\
\hline 9 & 91 & 82 & 0 & 19 & 6 & 92 & 0.07 \\
\hline${ }^{*} 10$ & $81(88) \dagger$ & $12(15)$ & $5(2) \dagger$ & $68(80) \dagger$ & $0(0) \dagger$ & $92(90) \dagger$ & 0 \\
\hline$* 11$ & $88(91) \dagger$ & $12(8)$ & $3(7) \dagger$ & $74(78) \dagger$ & $20(17) \dagger$ & $70(75) \dagger$ & 0.29 \\
\hline$* 12$ & 94 & 62 & 21 & 13 & 87 & 9 & $9 \cdot 7$ \\
\hline 13 & 40 & 2 & 3 & 26 & 30 & 10 & $3 \cdot 0$ \\
\hline 14 & 31 & 22 & 1 & 12 & 25 & 6 & $4 \cdot 1$ \\
\hline$* 15$ & 100 & 0 & 3 & 95 & 95 & 5 & $19 \cdot 0$ \\
\hline \multicolumn{8}{|l|}{ Mean } \\
\hline \pm s.e. mean) & $61 \cdot 5(6 \cdot 9)$ & $22 \cdot 4(6 \cdot 7)$ & $4 \cdot 2(1 \cdot 3)$ & $36 \cdot 2(6 \cdot 3)$ & $34 \cdot 4(7 \cdot 8)$ & $30 \cdot 8(8 \cdot 7)$ & \\
\hline Range & $27-100$ & $0-82$ & $0-21$ & $10-95$ & $0-95$ & 0-92 & \\
\hline \multicolumn{8}{|l|}{ Patient } \\
\hline 16 & 100 & 7 & 5 & 98 & 20 & 97 & $0 \cdot 2$ \\
\hline$* 17$ & $25(100) \dagger$ & $4(30) \dagger$ & $7(4) \dagger$ & $20(90) \dagger$ & $22(100) \dagger$ & $10(0) \dagger$ & $2 \cdot 2$ \\
\hline$* 18$ & $44(48) \dagger$ & $32(36) \dagger$ & $4(2) \dagger$ & $15(12) \dagger$ & $28(34) \dagger$ & $18(15) \dagger$ & $1 \cdot 6$ \\
\hline
\end{tabular}

* Cells treated with trypsin before staining.

$\dagger$ Figures are obtained on lymphocytes extracted from lymph gland.

\begin{tabular}{lccccccc}
\hline Controls (13) \\
\hline Mean & & & & & & & \\
$( \pm$ s.e. mean) & $17 \cdot 4(1 \cdot 3)$ & $7 \cdot 9(1 \cdot 4)$ & $1 \cdot 5(0 \cdot 4)$ & $9 \cdot 5(0 \cdot 9)$ & $12 \cdot 0(0 \cdot 9)$ & $7 \cdot 1(0 \cdot 5)$ & $1 \cdot 7$ \\
Range & $10-25$ & $2-18$ & $0-4$ & $5-17$ & $8-18$ & $3-11$ & $1 \cdot 1-3 \cdot 3$ \\
\hline
\end{tabular}


Comparison of lymphocytes in blood and lymph node

In 3 patients with CLL and 2 with lymphoma lymphocytes from these 2 sources were compared. In the 3 patients with CLL identical results were obtained from blood and gland lymphocytes, as was the case with one patient with lymphoma.

In the second patient with lymphosarcoma, $90 \%$ of the lymphocytes from the gland carried IgM immunoglobulins and all had $\kappa$ light chains. The blood lymphocytes were normal.

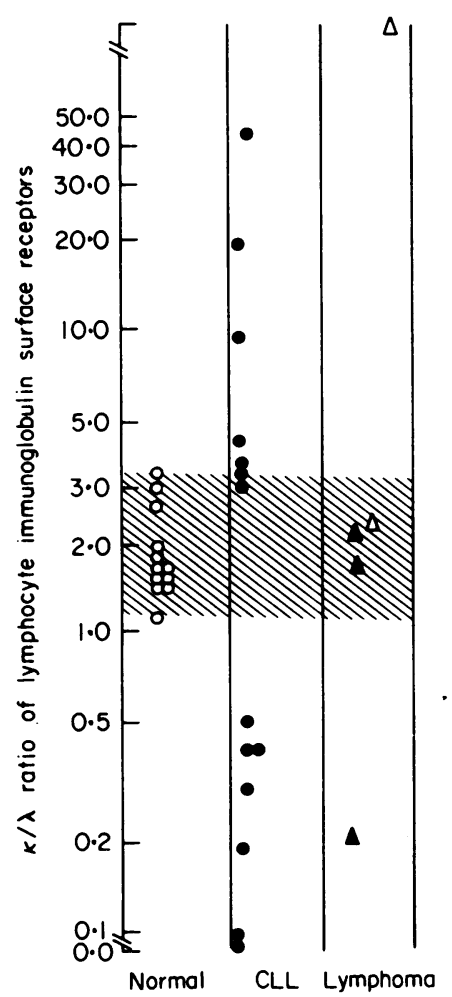

FIG. 2. Ratio of lymphocytes reacting with $\kappa$ and $\lambda$ antisera. $\bigcirc$ Normal, CLL, $\Delta$ lymphoma blood, $\triangle$ lymphoma lymph gland.

\section{Lymphocyte size (Fig. 3)}

Cells in CLL tended to be larger than lymphocytes from normal subjects. In controls the cell diameters were mainly between 5.6 to $8.5 \mu$ whereas in CLL the majority of lymphocytes were between $7 \cdot 6$ to $10 \cdot 5 \mu$.

\section{Cell-mediated immunity (Table 5)}

All 9 controls became sensitized following application of DNCB whereas only 8 of 15 patients with CLL and one out of 3 lymphoma patients responded. A positive PPD test was found in about

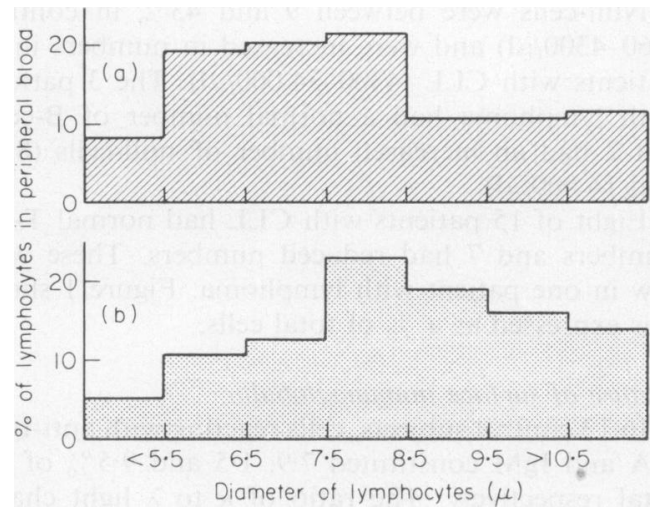

FIG. 3. Size of lymphocytes assessed in Coulter Counter Model B in (a) normal (18) patients and (b) CLL (14) G patients.

TABLE 5. Tests for cell-mediated immunity

\begin{tabular}{lccc}
\hline & \multicolumn{3}{c}{ Number positive/number tested } \\
\cline { 2 - 4 } & Controls & CLL & Lymphoma \\
\hline DNCB & $9 / 9$ & $8 / 15$ & $1 / 3$ \\
PPD & $4 / 10$ & $8 / 15$ & $0 / 3$ \\
Candida & $9 / 10$ & $9 / 15$ & $1 / 3$ \\
Mumps & $8 / 10$ & $7 / 15$ & $1 / 3$ \\
\hline DNCB = dinitrochlorobenzene. & \\
PPD = purified protein derivative (tuberculin).
\end{tabular}

$50 \%$ of the controls and patients. Nine of 痛 controls reacted to Candida and 8 of 10 to mump antigen, whereas only 9 of 15 and 7 of 15 CLI patients responded.

The mildly affected patients who did not requie treatment (cases 1 to 6 ) tended to respond positively whereas the patient who required treatment showed impaired responsiveness. Thus $75 \%$ of tests wee positive in cases 1 to 6 , whereas only $39 \%$ were positive in cases 7 to 15 . In particular, the DNCB test was positive in cases 1 to 6 and only in cases 10 and 14 of the remaining patients.

\section{Humoral immunity}

Serum immunoglobulins. Serum IgG, IgA and IgM levels were reduced in 3,5 and 6 out of patients with CLL respectively. IgA was reduced in one patient with lymphoma and IgM reduced in alf3 lymphoma patients. The reduced IgG levels in the CLL patients were $2 \cdot 7,2 \cdot 8$ and $4 \cdot 4 \mathrm{~g} / \mathrm{l}$ (normal range 6-17 $\mathrm{g} / \mathrm{l})$, reduced IgA levels were $0 \cdot 1,0 \cdot 2,0 \cdot 3,0.5$ and $0.4 \mathrm{~g} / \mathrm{l}$ (normal range $0.5-2.2 \mathrm{~g} / \mathrm{l}$ ) and reduced IgM levels were $<0.1,0.2,0.3,0.3,0.4$ and 0.5 g (normal range $0.6-2 \mathrm{~g} / \mathrm{l}$ ). The reduced levels were found in the more severely affected patients. Threa patients had low levels of all the immunoglobulim 
(13, 14 and 15$)$ and 2 reduced $\operatorname{IgA}$ and IgM only (cases 10 and 11).

Response to pneumococcal polysaccharide type III. Thirteen control subjects showed a serum antibody titre 12-14 days after injection which ranged from $1 / 128$ to $1 / 4096$ (Fig. 4). Only 1 out of 10 patients with CLL reached a titre of 128 after sensitization. Two patients with lymphoma also showed a poor response. Treatment of the sera with 2-mercaptoethanol showed that the antibody was both IgG and IgM.

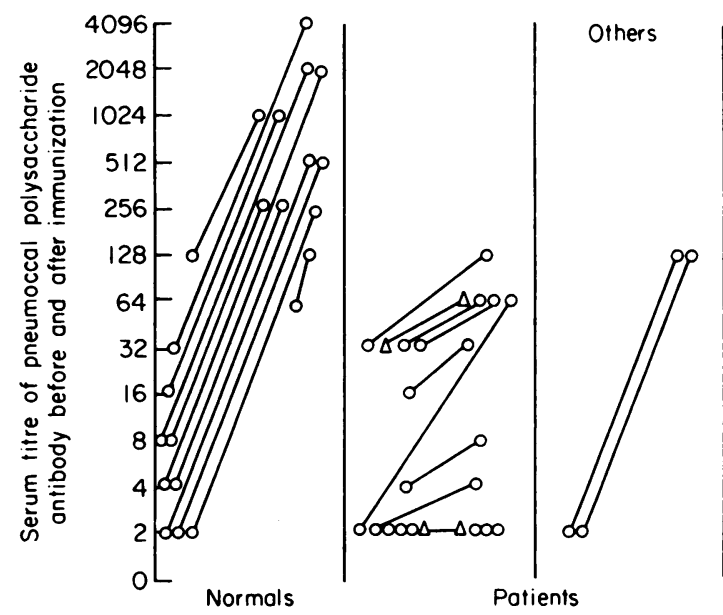

FIG. 4. Rise in titre of pneumococcal polysaccharide antibody. $\triangle$ Lymphoma, $O$ CLL.

E. coli antibodies. Antibodies were found in all of 18 control sera tested, the lowest titre being 1 in 64. Eight of 15 patients with CLL had $E$. coli antibody titres of $<64$ as did 2 of 3 patients with lymphoma. Patients with CLL not requiring treatment had normal titres, and low titres were found in the more severely affected patients.

Antibody to Staph. aureus, $\mathrm{H}$. influenzae and E. coli (intradermal tests). Positive results were obtained in 9 of 10 controls with Staph. aureus, in all 10 controls with $H$. influenzae and in 9 of 10 controls with $E$. coli.

Seven of 15 CLL patients gave positive results with Staph. aureus, 15 of 15 were positive with $H$. influenzae and 12 of 15 were positive with $E$. coli. Failure to respond occurred in the more severely affected patients, although one patient who did not require treatment (case 6) was negative to E. coli.

\section{The effect of treatment}

Tests were repeated in 13 out of 18 patients. Three died and the tests were not repeated in 2 mildly affected patients who did not require treatment.
Three other patients were retested not less than one year after the initial study although they were not treated. Nine treated patients with CLL were in 2 groups. Five patients (cases 5, 7, 11, 12 and 13) responded well to treatment with chlorambucil and 4 (cases 8, 9, 10 and 15) did not. Those who responded showed a marked decline in the proportion of null-cells, which disappeared in 2 patients (Table 3). In 3, the percentage of B-cells increased, remained unchanged in one and fell in a third. In all the percentage of $\mathrm{T}$-cells rose.

In those failing to respond, the percentage of nullcells increased in 3 and was unchanged in the fourth. The percentage of B-cells and the percentage of T-cells increased with the fall in total lymphocyte numbers.

In the patient with lymphosarcoma the null-cells disappeared from the blood after treatment and the percentage of B-cells increased. Results are summarized in Fig. 1.

In cases 5 and 7 , the satisfactory response was accompanied by decline in the numbers of lymphocytes with IgM and $\kappa$ markers (Table 6). In case 8, who did not respond, the IgM-producing cells increased.

TABLE 6. Comparison between lymphocytes carrying surface receptors before (a) and after (b) treatment

Percentage of stained cells using the following antisera

\begin{tabular}{ccrrrrr}
\cline { 2 - 6 } Patient & Polyvalent & IgG & IgA & IgM & $\kappa$ & $\lambda$ \\
\hline 5a & 88 & 12 & 6 & 56 & 80 & 18 \\
5b & 29 & 8 & 6 & 8 & 24 & 12 \\
$7 \mathrm{a}$ & 46 & 10 & 4 & 33 & 44 & 13 \\
$7 \mathrm{~b}$ & 24 & 13 & 5 & 9 & 21 & 5 \\
8a & 46 & 2 & 5 & 35 & 45 & 0 \\
$8 \mathrm{~b}$ & 100 & 44 & 5 & 68 & 72 & 30 \\
$17 \mathrm{a}$ & 25 & 4 & 7 & 20 & 22 & 10 \\
$17 \mathrm{~b}$ & 16 & 6 & 0 & 13 & 14 & 3 \\
\hline
\end{tabular}

Re-testing of 3 patients with CLL who were not treated (cases 1, 4 and 6) showed an increase in Bcells at the expense of null-cells. The PPD and DNCB skin tests were repeated as described either after treatment or in the untreated patients after one year. In 3 patients with CLL the results remained unchanged. Tests in 8 patients with CLL repeated after treatment are summarized in Table 7.

TABLE 7. Effect of treatment on cell-mediated immunity in chronic lymphocytic leukaemia

\begin{tabular}{lcc}
\hline & \multicolumn{2}{c}{ Number positive/number tested } \\
\cline { 2 - 3 } & Before treatment & After treatment \\
\hline PPD & $4 / 8$ & $3^{*} / 8$ \\
DNCB & $2 / 8$ & $1^{*} / 8$ \\
\hline
\end{tabular}

* Including one patient who was initially negative. 
One patient received treatment with prednisone followed by chlorambucil and subsequently by cyclophosphamide over a 2-year period. She was reasonably well but the total lymphocyte count was always approximately $40000 / \mu 1$. Initially she gave negative results when tested with PPD and DNCB. On re-testing 7 weeks after stopping treatment she gave a very strongly positive response to PPD and an alarming response to DNCB with massive weal formation and oedema of the arm. Prednisone $60 \mathrm{mg} /$ day was started after $24 \mathrm{hr}$ and oedema subsided leaving an ulcerated area which healed normally.

Six other patients had good clinical responses to chlorambucil therapy, in some preceded by prednisone therapy. These patients were retested in remission 6 or more weeks after cessation of therapy. In 4 of these patients there was no change in the way they reacted to PPD and DNCB. In one patient receiving chlorambucil alone and who had a good clinical response, a positive response to DNCB was followed by a negative one in remission. A second patient who responded to a combination of prednisone and chlorambucil lost his initially positive response to PPD.

There was no change in immunoglobulin levels after treatment.

Thus, following treatment the patients' immune responses were either unchanged or continued to decline.

One patient with lymphosarcoma was treated with 6 courses of MOPP at 2-monthly intervals. He initially gave a negative PPD and a strongly positive DNCB test. The latter became negative after treatment.

\section{Discussion}

The observations reviewed in the introduction concerning the B-cell origin of CLL have been confirmed in this study, almost all the patients showing increased numbers of B-lymphocytes. In addition, there were, as noted by others, lymphocytes which had surface immunoglobulin but lacked complement receptors (Seligmann, 1974). Furthermore, cells which react with heat-aggregated immunoglobulin while failing to react with an antiIgG serum do occur (Davis, 1976). These cells are similar to the cells termed null-cells in this paper. A new observation is the great susceptibility of these null-cells to the effects of antileukaemic agents. In those patients who responded to drugs such as chlorambucil, the fall in lymphocyte numbers was due mainly to the considerable fall in the numbers of null-cells. However, the relative proportion of $\mathbf{B}$ and null-cells may vary at different stages of the disease, without treatment, as shown in the untreated cases as well as by Davis (1976).
The clonal origin of CLL recently reviewed b\%̆ Fialkow (1976) and Greaves (1975) is confirmed iके these studies by the preponderance of either a $\kappa$ or light chain on the cell surface.

Comparison of cells in peripheral blood an $\overrightarrow{\overline{\mathbf{\phi}}}$ lymph gland shows that in CLL the cells were identical. In one patient with lymphocytic lymphom gland cells were all B lymphocytes with $\kappa$ light chainş. whereas lymphocytes from peripheral blood were normal, indicating the localized origin of this clonad disease.

Cells in CLL tend to be larger than normal lym $\vec{?}$ phocytes but this does not apply to all the patients.

The failure of immune responses and the associate hypogammaglobulinaemia is well known (sed introduction). In all the tests the patients with CLB. showed significant impairment as compared toir controls and humoral immunity was more severeløु impaired than cell-mediated immunity. The moser satisfactory test was the response to a challenge ofo pneumococcal polysaccharide which was impaired in 14 out of 15 patients with CLL. It was abnormaP even in those patients who were in good health or whose only manifestation was an elevated lympho $\frac{8}{8}$ cytic count.

Finally, the effect of treatment in those wh\& responded was to reduce the number of lymphocxtes. and hence reduce lymphadenopathy and size infiltrated organs. Removal of lymphocytes from marrow may have led to a rise in the red cell coumt neutrophils and platelets. Their immune capacitys however, was not benefited by treatment but at the best remained unchanged or continued to decline This is in contrast with acute adult leukaemia where improvement in immune status indicated a likel response to chemotherapy (Hersh et al., 1971).

\section{References}

Augner, W., Cohnen, G. \& Brittinger, G. (1974) Binding of aggregated IgG by lymphocytes in chronic lymphocytie?. leukemia. Biomedicine, 21, 6.

Barker, P.J., Stashak, P.W. \& Prescott, B. (1969) Use of erythrocyte sensitized with purified pneumococcal polysaccharides for the assay of antibody and antibodi producing cells. Applied Microbiology, 17, 422.

BAZERBASHI, M.B. (1975) The immune status of patients wit chronic lymphocytic leukaemia. Ph.D. thesis, University of London.

BoGGS, D.R. \& FAHEY, J.L. (1960) Serum protein changes in malignant disease. II. Chronic leukemias, Hodgkin's diseasత్ and malignant melanoma. Journal of the National Cance Institute, 25, 1381.

BuCKLEY, C.E. \& DoRey, F.C. (1971) Serum immuno globulin levels throughout life span of healthy mane Annals of Internal Medicine. 75, 673.

Cohnen, G., Doglas, D.S., König, E. \& Brittinger, G⿺ (1974) Pokeweed mitogen response of lymphocytes in chronic lymphocytic leukemia: fine structural study Blood, 42, 591. 
Davis, S. (1976) The variable pattern of circulating lymphocyte subpopulations in chronic lymphocytic leukemia. New England Journal of Medicine, 21, 1150.

Dickler, H.B., Siegal, F.B., Bentwich, Z.H. \& Kunke, H.G. (1973) Lymphocyte binding of aggregated IgG and surface Ig staining in chronic lymphocytic leukaemia. Clinical and Experimental Immunology, 14, 97.

FAIRLEY, G.H. \& SCOTT, R.B. (1961) Hypogammaglobulinaemia in chronic lymphatic leukaemia. British Medical Journal, 2, 920.

Fernandez, J.M., MacSween, M.J. \& Langley, G.R. (1975) Separation of T-lymphocytes from normal individuals and patients with B-lymphocyte chronic lymphocytic leukaemia. Immunology, 28, 231.

FIALKOW, P.J. (1976) Clonal origin of human tumors. Biochimica et biophysica acta, 458, 283.

Fu, S.M. \& KunKel, H.G. (1974) Membrane immunoglobulins of B-lymphocytes. Inability to detect certain characteristic IgM and IgD antigens. Journal of Experimental Medicine, 140, 895.

Gold, E.R. \& FudenberG, H.H. (1967) Chromic chloride: A coupling reagent for passive haemagglutination reaction. Immunology, 99, 859.

Greaves, M.F. (1975) Clinical applications of cell surface markers. In: Progress in Hematology. IX. (Ed. by Brown, E.B.) Grune \& Stratton, New York.

Haegert, D.G., Hallberg, T. \& Coombs, R.R.A. (1974) $\mathrm{B}$ and $\mathrm{T}$ lymphocyte sub-populations in human peripheral blood. International Archives of Allergy and Applied Immunology, 46, 535.

HANSEN, M.M. (1973) Chronic Lymphocytic Leukaemia. Clinical Studies Based on 189 Cases Followed for a Long Time. Munksgaard, Copenhagen.

Hersh, E.M., Whitecar Jr, J.P., McCredie, K.B., Bodey Sr, G.P. \& Freireich, E.J. (1971) Chemotherapy, immunocompetence, immunosuppression and prognosis in acute leukemia. New England Journal of Medicine, 285, 1211.

Huber, C., Michlmayr, G. \& Huber, H. (1974) Immunologische Marker in der differentialdiagnose lymphatischer Systemerkrankungen. Deutsche medizinische Wochenschrift, 99, 2262.

JIM, R.T.S. (1957) Serum gamma globulin levels in chronic lymphocytic leukemia. American Journal of Medical Sciences, 234, 44.

Jondal, M., Holm, G. \& Wigzell, H. (1972) Surface markers on human $B$ and $T$ lymphocytes. I. A large population of lymphocytes forming non-immune rosettes with sheep red blood cells. Journal of Experimental Medicine, 136, 207.

Kubo, R.T., Grey, H.M. \& Pirofsky, B. (1974) IgD: a major immunoglobulin on the surface of lymphocytes from patients with chronic lymphatic leukemia. Journal of Immunology, 112, 1952.

Mancini, G., Carbonara, A.O. \& Herman, J.F. (1965) Immunochemical quantitation of antigen by single radial immunodiffusion. Immunochemistry, 2, 235.

Melief, C.J., Schweitzer, M. \& Eijsvoogel, V.P. (1973) Lymphocytes transformation in vitro. V. Thyminidine incorporation into unstimulated lymphocytes. Experimental Cell Research, 79, 257.

Miller, D.G. (1962) Patterns of immunological deficiency in lymphomas and leukemias. Annals of Internal Medicine, 57, 703 .

MobaraK, M A. \& Brody, J.I. (1967) Quantitative immunoglobulin assays in patients with lymphatic neoplasms. Pennsylvania Medicine, 70, 99.

Nath, I., Curtis, J., Mangalik, A. \& Talwar, P.G. (1975) Lymphocytes devoid of $T$ and $B$ cell marker in chronic lymphatic leukemia. Acta haematologica, 53, 37
Papamichail, M., Brown, J.C. \& Holborow, E.J. (1971) Immunoglobulins on the surface of human lymphocytes. Lancet, ii, 850.

Pernis, P., Ferrarini, M., Forni, C. \& Amante, L. (1971) Immunoglobulins on lymphocyte membranes. In: Progress in Immunology, p. 95, Academic Press, New York, London.

Pincus, S., Bianco, C. \& Nussenzweig, V. (1972) Increased proportion of complement receptor lymphocytes in peripheral blood of patients with chronic lymphocytic leukemia. Blood, 40, 304.

Preud'Homme, J.L. \& Seligmann, M. (1972) Surface-bound immunoglobulin as a cell marker in human lymphoproliferative diseases. Blood, 40, 777.

Rabillino, E. \& GREY, H.M. (1972) Characteristics of lymphocytes associated immunoglobulins in chronic lymphocytic leukaemia. Federation Proceedings. Federation of American Societies for Experimental Biology, 31, 610.

Ross, G.D., Rabillino, E., Polley, M.J. \& Grey, H.M. (1973) Combined studies of complement receptor and surface immunoglobulin bearing cells and sheep erythrocyte rosette-forming cells in normal and leukemic lymphocytes. Journal of Clinical Investigation, 52, 377.

Scamps, R.A., Streeter, A.M. \& O'Neill, B.J. (1971) Immunoglobulins in chronic lymphocytic leukaemia. Medical Journal of Australia, 1, 535.

SchumanN, G. (1963) Serumeiweiss-veranderungen bei Hämoblastosen. Deutsche Gesundheitswesen, 18, 2034.

SeligmanN, M. (1974) B-cell and T-cell markers in lymphoid proliferations. New England Journal of Medicine, 290, 1483.

SeligmanN, M. (1975) Membrane cell markers in human leukaemias and lymphomas. British Journal of Haematology, 31 (Suppl.), 1.

Seligmann, M., Preud'Homme, J.L. \& Brouet, J.-C. (1973) $B$ and $T$ cell markers in human proliferative blood diseases and primary immunodeficiencies, with special reference to membrane-bound immunoglobulins. Transplantation $\mathrm{Re}$ views, 17, 85 .

Shevach, E.M., Herberman, R. \& Frank, M.M. (1972) Receptors for complement and immunoglobulins on human leukemia cells, and human lymphoblastoid cell lines. Journal of Clinical Investigation, 51, 1933.

SlungaARd, R. \& SMith, M.J. (1974) Serum immunoglobulin levels in chronic lymphocytic leukaemia. Scandinavian Journal of Haematology, 12, 112.

Unanue, E.R., Grey, H.M., Rabillino, E., Campbell, P. \& SCHMidTKE, J. (1971) Immunoglobulins on the surface of lymphocytes. II. The bone marrow as the main source of lymphocytes with detectable surface bound immunoglobulins. Journal of Experimental Medicine, 133, 1188.

Van Boxel, J.A., Paul, W., Terry, W.D. \& Green, I. (1972a) IgD-bearing human lymphocytes. Journal of Immunology, 109, 648.

Van Boxel, J.A., Stabo, J.D., Paul, W.E. \& Green, I. (1972b) Antibody-dependent lymphoid cell-mediated cytotoxicity: No requirement for thymus-derived lymphocytes. Science. New York, etc., 175, 194.

VidebaeK, AA. (1949) Do malignant lymphomas represent varying differentiation of growth? Acta haematologica, 2, 201.

Webster, A.D.B., EfTer, T. \& Asherson, G.L. (1974) Escherichia coli antibody. A screening test for immunodeficiency. British Medical Journal, 3, 16.

WILSON, J.D. \& NossaL, G.J.V. (1971) Identification of human $T$ and $B$ lymphocytes in normal peripheral blood and in chronic lymphocytic leukaemia. Lancet, ii, 788.

Wybran, J., Chantler, S. \& Fudenberg, H.H. (1973) Isolation of normal T-cells in chronic lymphatic leukaemia. Lancet, i, 126. 